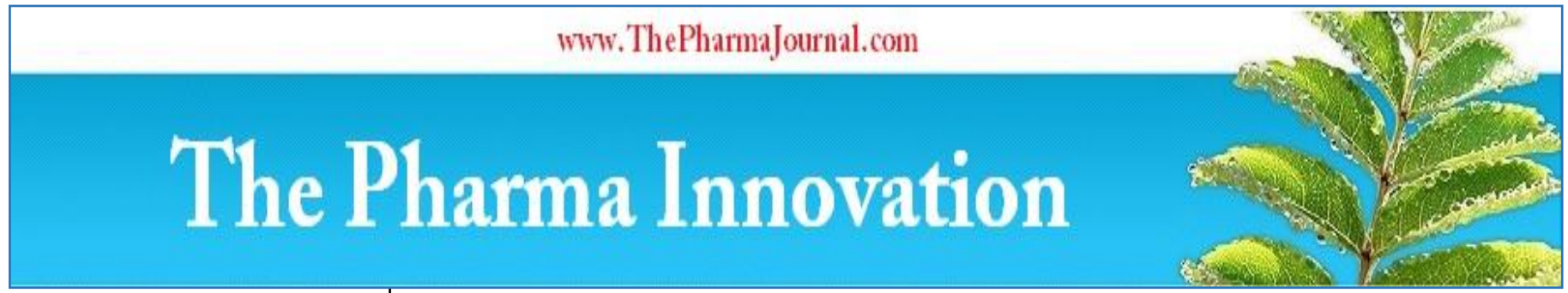

ISSN (E): 2277- 7695

ISSN (P): 2349-8242

NAAS Rating: 5.03

TPI 2020; SP-9(7): 194-195

(C) 2020 TPI

www.thepharmajournal.com

Received: 04-05-2020

Accepted: 06-06-2020

\section{S Pavithra}

Ph.D Scholar, Department of Veterinary Pharmacology,

Indian Veterinary Research

Institute, Izatnagar, Bareilly,

Uttar Pradesh, India

M Thirunavukkarasu

Assistant Professor, Department

of Veterinary and Animal

Sciences, TNAU, Coimbatore,

Tamil Nadu, India

\section{S Shanmuganathan}

Ph.D Scholar, Department of

Veterinary Virology, Indian

Veterinary Research Institute

Bangalore, Karnataka, India

\section{P Rajkumar}

M.V.Sc Scholar, Department of

Livestock Production

Management, Indian Veterinary

Research Institute, Izatnagar,

Bareilly, Uttar Pradesh, India
Corresponding Author:

\section{S Pavithra}

Ph.D Scholar, Department of Veterinary Pharmacology, Indian Veterinary Research Institute, Izatnagar, Bareilly, Uttar Pradesh, India

\section{Caprine papillomatosis: A case report}

\section{S Pavithra, M Thirunavukkarasu, S Shanmuganathan and P Rajkumar}

\section{DOI: https://doi.org/10.22271/tpi.2020.v9.i7Sd.4958}

Abstract

A six month old farm bred male Telicherry kid presented with multiple skin eruptions in various parts of the body and emaciated which was diagnosed as a case of Papillomatosis. The Hematological and Histopathological examinations were carried out for confirmation and the findings are discussed.

Keywords: Goat-telicherry kid, papilloma, histopathology

\section{Introduction}

Caprine papillomatosis is a contagious disease occurring as warts/papilloma on skin and mucosa, predisposed by several facors viz., non-pigmented skin, age, excessive exposure to ultraviolet light (Ginn et al., 2007) ${ }^{[3]}$ and contact with papilloma virus (Goldschmidt et al., 1998) ${ }^{[2]}$. Papillomatosis in goat can result in retarded growth and weight loss. The quality of the hide is also deteriorated. The disease may lead to a serious economic loss if not diagnosed and treated promptly. The present clinical report describes the diagnosis of Caprine papillomatosis in a farm bred kid by histopathological examination.

\section{Case History and Observation}

A six month old male Telicherry kid maintained in Tamilnadu Agricultural University Goat farm was presented with history of multiple cutaneous skin eruptions found various parts of the body. The animal showed restlessness, irritation and retarded growth. Skin biopsy was done and tissue samples were collected from different parts of body and fixed with $10 \%$ buffered formalin subjected to histopathological examination. Blood sample was also collected and subjected to routine analysis.

\section{Results and Discussion}

Clinical examination of goat revealed that skin eruptions are found to be ulcerated wound with bleeding in parts such as lion and medial thigh regions and cauliflower like growth found ventral to the anus (Fig 1 and 2) was similar to the description made by Radostits et al., (2007) [5]. The results of the histopathological examination of skin samples revealed that finger like proliferation of the dermis and sub -mucosa thrown into folds of projections with hyperkeratosis which was concurrent with the results of Sule et al., (2011) ${ }^{[6]}$. Hematological examination revealed that severe anemia and other blood parameters were within normal range which is similar to the findings of Barakat et al., (2013) ${ }^{[1]}$.

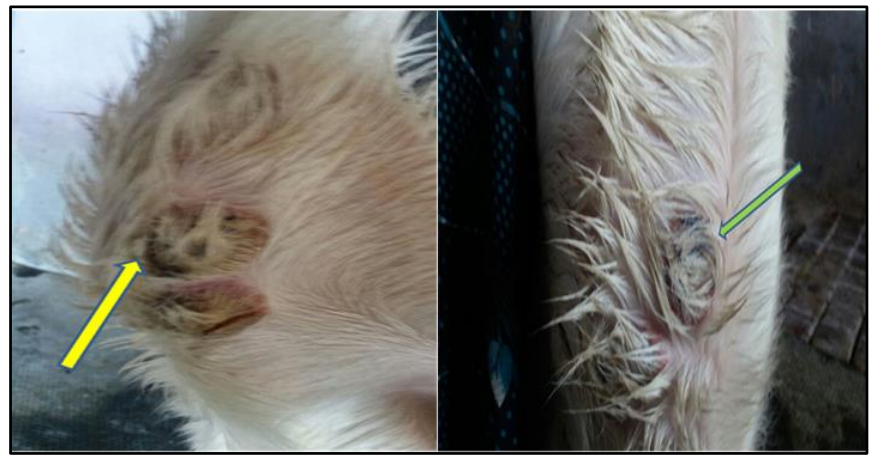

Fig 1 \& 2: Kid with Papillomatous lesion $\sim 194 \sim$ 


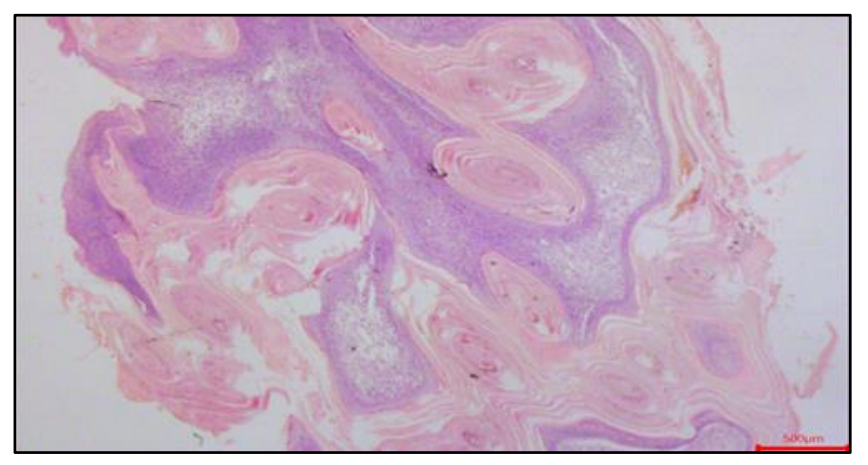

Fig 3: Histopathological lesion of papilloma

The present case report was confirmed as Caprine Papillomatosis based on the histopathology. Occurrence of anemia in association with the Caprine Papillomatosis may be due to decrease in food intake which is concurrent with the emaciated appearance of the animal.

\section{Summary}

Caprine Papillomatosis of Tellicherry goat kid was successfully diagnosed and reported.

\section{References}

1. Barakat SEM, Hizab FAAL, Bahr SME. Clinicopathological and Serobiochemical Investigation of Naturally Occurring Cutaneous Papillomatosis in Dromedary Camels (Camelus dromedarius). Science International. 2013; 1(6):212-216.

2. Goldschmidt MH, Dunstan RW, Stannard AA, Von Tscharne C, Walder EJ, Yager JA et al. Histological classification of epithelial and melanocytic tumors of the skin of domestic animals, $2^{\text {nd }}$ series, Vol. III, Washington, D.C. Armed Forces Institute of Pathology, 1998, 19-20.

3. Ginn, PE, Mansell EKL, Rakich PM. Skin and appendages. Jubb, Kennedy and Palmers Pathology of Domestic Animals, Edn V, Vol I, Elsevier Ltd, Philadelphia, 2007, 647-648.

4. Radostits, OM, Gay CC, Hinchcliff, KW Constable, PD. Veterinary Medicine, Edn X Saunders-Elsevier, New York, USA, 2007, 1723.

5. Şule YZ, Zafer O, Murat G. Clinical, Pathological and Immunohistochemical findings of bovine cutaneous papillomatosis. Ankara Univ Vet Fak Derg, 2011; 58:161-165. 